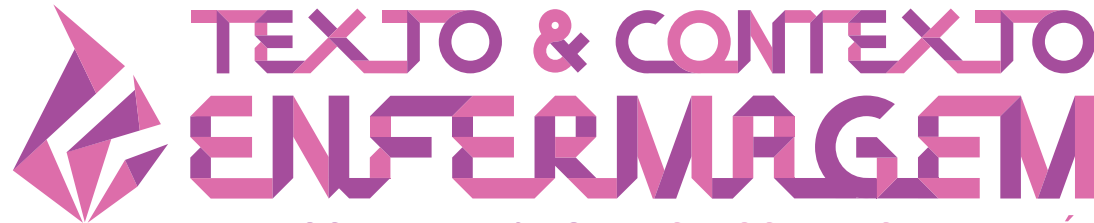

TEXT \& CONTEXT NURSING TEXTO \& CONTEXTO ENFERMERÍA

\section{PARENTING PRACTICES AND THE CHILD'S EATING BEHAVIOR}

\author{
Kelly de Freitas Santos ${ }^{1}$ \\ Mayra Alves dos Reis ${ }^{1}$ \\ Márcia Christina Caetano Romano ${ }^{1}$ (D)
}

${ }^{1}$ Universidade Federal de São João Del-Rei, Programa de Pós-Graduação em Enfermagem. Divinopolis, Minas Gerais, Brasil.

\begin{abstract}
Objective: to investigate the association between the parenting practices and the child's eating behavior. Method: a cross-sectional study, conducted with 368 children aged from one to five years old, registered in the Family Health Strategy units of the urban area of the municipality of Divinópolis-MG. An anthropometric assessment was performed to classify the children's nutritional status. Information was collected from January to September 2019 referring to demographic and socioeconomic data, as well as to lifestyle, health status, diabetes, parenting practices, and children's eating behavior. The child's eating behavior was assessed by means of a food frequency questionnaire, where the daily consumption of ultra-processed foods was estimated. Multiple linear regression was used to assess the association between parenting practices and the child's eating behavior, with a significance level of $5 \%$.

Results: greater consumption of ultra-processed foods was identified when the parents used physical force $(p<0.018)$, reward for eating $(p<0.002)$, and food restriction $(p<0.011)$ practices. A negative association with the consumption of ultra-processed foods was evidenced when the parents provided guidance for healthy eating $(p<0.006)$, authoritative monitoring $(p<0.017)$, and positive reinforcement of the children's behavior that is considered adequate $(p<0.046)$.

Conclusion: the results of this study evidenced that the parenting practices were associated with the children's eating behavior. Therefore, research studies on the determinants of this behavior are recommended.
\end{abstract}

DESCRIPTORS: Eating behavior. Child. Family. Psychology. Food. 


\section{PRÁTICAS PARENTAIS E COMPORTAMENTO ALIMENTAR DA CRIANÇA}

\section{RESUMO}

Objetivo: avaliar a associação entre as práticas parentais e comportamento alimentar da criança.

Método: estudo transversal, realizado com 368 crianças de um a cinco anos de idade, cadastradas nas Estratégias de Saúde da Família da zona urbana do município de Divinópolis-MG. Realizou-se avaliação antropométrica para classificação do estado nutricional das crianças. Coletaram-se informações de janeiro a setembro de 2019 referentes a dados demográficos, socioeconômicos, estilo de vida, estado de saúde, dietéticos, práticas parentais e comportamento alimentar das crianças. O comportamento alimentar da criança foi avaliado por meio do questionário de frequência alimentar, onde se estimou o consumo diário de alimentos ultraprocessados. Regressão linear múltipla foi usada para avaliar a associação de práticas parentais e comportamento alimentar da criança, com um nível de significância de $5 \%$.

Resultados: identificou-se um maior consumo de alimentos ultraprocessados quando os pais realizavam práticas de força física $(p<0,018)$, recompensa para comer $(p<0,002)$ e restrição alimentar $(p<0,011)$. Associação negativa com o consumo de ultraprocessados foi evidenciada quando os pais realizavam orientação para alimentação saudável $(p<0,006)$, monitoramento autoritativo $(p<0,017)$ e reforço positivo ao comportamento infantil considerado adequado $(p<0,046)$.

Conclusão: os resultados deste estudo evidenciaram que práticas parentais associam-se ao comportamento alimentar das crianças. Portanto, recomendam-se investigações acerca dos determinantes desse comportamento.

DESCRITORES: Comportamento alimentar. Criança. Família. Psicologia. Alimentos.

\section{PRÁCTICAS PARENTALES Y COMPORTAMIENTO ALIMENTARIO DEL NIÑO}

\section{RESUMEN}

Objetivo: evaluar la asociación entre las prácticas parentales y el comportamiento alimentario del niño.

Método: estudio transversal, realizado con 368 niños de uno a cinco años de edad, registrados en las unidades de Estrategia de Salud Familiar de la zona urbana del municipio de Divinópolis-MG. Se realizó una evaluación antropométrica de enero a septiembre de 2019 para clasificar el estado nutricional de los niños. Se recolectó información referente a datos demográficos y socioeconómicos, sobre estilo de vida, estado de salud, relacionados con dietas, prácticas parentales y comportamiento alimentario de los niños. El comportamiento alimentario del niño se evaluó por medio del cuestionario de frecuencia alimentaria, donde se estimó el consumo diario de alimentos ultra procesados. Se empleó regresión lineal múltiple para evaluar la asociación entre las prácticas parentales y el comportamiento alimentario del niño, con un nivel de significancia del $5 \%$.

Resultados: se identificó un mayor consumo de alimentos ultra procesados cuando los padres empleaban prácticas de fuerza física $(p<0,018)$, recompensas para comer $(p<0,002)$ y restricción alimentaria $(p<0,011)$. Se hizo evidente una asociación negativa con el consumo de alimentos ultra procesados cuando los padres ofrecían pautas de orientación para una alimentación saludable $(p<0,006)$, control con autoridad $(p<0,017)$ y refuerzo positivo del comportamiento infantil considerado adecuado $(p<0,046)$.

Conclusión: los resultados de este estudio evidenciaron que las prácticas parentales están asociadas con el comportamiento alimentario de los niños. En consecuencia, se recomienda realizar estudios de investigación acerca de los determinantes de dicho comportamiento.

DESCRIPTORES: Comportamiento alimentario. Niño. Familia. Psicología. Alimentos. 


\section{INTRODUCTION}

The eating behavior refers to a very complex phenomenon, since the act of eating goes much beyond the basic nutritional needs, being fundamental to human development and to meeting the physiological and pleasurable needs. ${ }^{1}$ There is evidence that adequate eating behaviors in the first years of life are known to prevent inappropriate eating behaviors in adulthood. Breastfeeding is the first determinant of the eating behavior, a mediating factor for self-regulation of hunger and satiety. ${ }^{2}$

Eating patterns are changing rapidly worldwide, and the topic of eating behavior has gained relevance today, due to its implications on determining prevalent chronic diseases such as diabetes mellitus, obesity and systemic arterial hypertension, among others. ${ }^{3-4}$ A rapid change in children's eating behavior has been notices, with worsening in the overall quality of the children's diet, characterized by reduced consumption of fruits, vegetables, and fibers and by increased consumption of ultraprocessed foods rich in sugar, saturated fat, and sodium. ${ }^{5}$

The relationship between parenting practices and children's eating behavior has been studied, especially in the international literature. ${ }^{6}$ However, such studies disregarded important variables in the causal model, such as socioeconomic level and cultural aspects, like breastfeeding. ${ }^{7-12}$

It is noted that the current national literature on parenting practices in relation to children's eating behavior is scarce and excessively focused on eating disorders. ${ }^{13}$

It is important to emphasize that early childhood, the period spanning from birth to five years of age, represents a crucial time in the process of modulation and development of the eating behavior. ${ }^{14}$ Therefore, it is a favorable period for conducting research studies on the determinants of this behavior.

The objective of this study is to assess the association between parenting practices and children's eating behavior.

\section{METHOD}

This is quantitative research study, of the cross-sectional type. The study was developed in the six planning regions that harbor their respective Family Health Strategy (FHS) units, located in the urban area of the Municipality of Divinópolis, MG. A random draw was performed with the FHS units of each planning region, stratifying the units that compose the study locus, totaling six units.

The population eligible for the study comprised 8,228 children aged from one to five incomplete years old, registered in the FHS units of the urban area in 2019. The exclusion criteria consisted in children with chronic diseases that implied specific diets, since this eating condition could interfere with the intimacy of the family nucleus. ${ }^{15}$

Sample size was calculated using the Open Epi program, version 3.01, for a confidence level of $95 \%$, a precision level of $5 \%$, and a proportion of $50 \%$ for outcomes of unknown prevalence, a value that provides the largest sample size for a finite population $(n=8,228)$, according to the criteria proposed in the literature, yielding an estimated sample of 368 children, with a $10 \%$ increase to compensate for possible losses and refusals. ${ }^{16}$

Data collection took place in the period from January to September 2019. The parents or guardians were interviewed and answered an identification form with demographic and clinical data, as well standardized questionnaires with questions referring to the socioeconomic characteristics, usual child's food intake, and parenting practices.

The children's anthropometric measures (weight and height) were taken as recommended by the Ministry of Health. ${ }^{15}$ The measurements were conducted in triplicate, and the arithmetic mean of the data obtained were subsequently calculated. The children's nutritional status was assessed using the WHO Anthro program, by the World Health Organization, to establish the z-score of the Body Mass Index (BMI) for age, classifying the children into those with extreme thinness $(z$-score $<-3)$, thinness (z-score $\geq-3$ and $z$-score $<-2$ ), eutrophy (z-score $>-2$ and $z$-score $\leq+1$ ), risk of excess 
weight (z-score $>+1$ and $z$-score $\leq+2)$, excess weight (z-score $>+2$ and z-score $\leq+3)$, obesity and severe obesity ( $z$-score $>+3$ ), according to the WHO curves. ${ }^{17}$

The family socioeconomic status was assessed by means of the questionnaire with criteria of socioeconomic classification by the Brazilian Association of Research Companies (Associação Brasileira de Empresas de Pesquisa, ABEP), which is based on the number of goods existing in the household (appliances and cars), presence of a salaried domestic helper, schooling level of the household head, and access to public services. ${ }^{18}$

The children's usual food intake was assessed by administering the questionnaire on food intake markers for children, subdivided into the ages of one to two incomplete years and of two years old or older, standardized by the Ministry of Health. ${ }^{19}$

The children's eating behavior was verified by administering a food frequency questionnaire (FFQ) for children from two to five years of age, validated for the Brazilian population, referring to consumption in the last year. ${ }^{20}$ The daily intake of ultra-processed foods was estimated, since a child's eating behavior marked by consumption of these foods is related to several negative health outcomes, such as obesity, dyslipidemia, and arterial hypertension. ${ }^{21}$

The consumption of ultra-processed foods, measured by means of the FFQ, was expressed as daily frequency and, therefore, the consumption frequency of once a day was converted into 1 , once a week was converted into $0.14(1 / 7)$, once a month was converted into $0.03(1 / 30)$, and so on. Ultraprocessed foods were defined as those that are ready-to-eat or ready-to-heat with little or no preparation. ${ }^{22}$

The explanatory outcomes adopted were the socioeconomic and demographic characteristics, health status, anthropometric data and parenting practices, as assessed by the Comprehensive Feeding Practices Questionnaire, validated, translated, and adapted to Brazilian parents and, to verify the parenting styles during meals, regarding the child's eating behavior, the Parental Feeding Styles Questionnaire (PFSQ) was applied, an instrument adapted and validated for the Brazilian context. ${ }^{23}$

The data collected were processed in the Epidata ${ }^{\circledR}$ program, version 3.1, which allowed for due data consistency and validation analysis. Data analysis was implemented in the Statistical Package for Social Sciences software, version 23.0 (SPSS Inc., Chicago, IL). A descriptive analysis of all the investigated variables was conducted by means of frequency distribution tables for the categorical variables; and measures of central tendency (mean), variability (standard deviation) and position (median, minimum and maximum) were used for the numerical variables.

The association between the parenting practices and the child's eating behavior was assessed using multivariate analysis by means of Multiple Linear Regression, with a significance level of $5 \%$. Only the variables that presented $p<0.20$ in the univariate model were selected to be included in the final model.

The entire research process and use of data followed the provisions of Resolution $\mathrm{N}^{\circ} .466$, of December $12^{\text {th }}, 2012$, by the National Health Council, on research involving human beings, according to approval by the Committee of Ethics in Research with Human Beings of the Federal University of São João del Rei.

\section{RESULTS}

Information was analyzed from a total of 368 children, whose mothers and fathers presented mean ages of $32( \pm 5.9)$ and 35 years old $( \pm 7.2)$, respectively. The Family Health Strategy unit that covered the greatest number of children to be assessed was that of the Southeast Region (25.5\%), and it was observed that more than a half of mothers $(58.3 \%)$ in this region worked outside their homes. With regard to the socioeconomic assessment, $3 \%$ of the investigated families belonged to class $\mathrm{A}$, $6.5 \%$ to class $B 1,19 \%$ to class $B 2,32.3 \%$ to class $C 1$, and $29.9 \%$ to class $C$, which represents the intermediate middle class, with $9.3 \%$ belonging to classes $\mathrm{D}$ and $\mathrm{E}$. 
More than half of the children were female (50.7\%). The predominant age of the children assessed was one year old (27.4\%) in relation to the other ages, with $75.4 \%$ of the total children assessed attending school in the afternoon period and presenting a mean sleep time of 11 hours a day $(29.3 \%)$. It was observed that $61.6 \%$ of the children were agitated and were not using any medication. $51.5 \%$ of the children were considered as brown-skinned. Most of the children presented normal bowel function (90.2\%). As for the previous clinical characteristics, $7 \%$ of the children were born prematurely, with predominance of cesarean delivery $(54.6 \%)$. The mean birth weight of the investigated children was $3.150 \mathrm{~kg}( \pm 0.51)$, and the mean birth height was $48.01 \mathrm{~cm}( \pm 2.39)$. As for the current anthropometric data, the mean height was $93.94 \mathrm{~cm}( \pm 11.87)$, and the mean weight was $14.5 \mathrm{~kg}( \pm 3.88)$. The nutritional status of the children participating in the study consisted of thinness (3.5\%), eutrophy (65\%), risk of excess weight (18.8\%), excess weight (8.5\%), and obesity $(4.1 \%)$.

As for the usual food intake of the children from 12 to 23 months old, the highest percentage of consumption was observed for salted meals (99\%) and the lowest consumption was for milk oatmeal, accounting for $4.9 \%$ of the group (Table 1 ).

With regard to the usual food intake of children aged over two years old, there was a significant consumption of processed and ultra-processed foods (Table 2).

Table 1 - Description of the data from the questionnaire on food intake markers, for children from one to 2 incomplete years of age, Divinópolis, MG, Brazil, 2019. $(n=102)$

\begin{tabular}{lccc}
\hline Consumption on the previous day & $\begin{array}{c}\text { No } \\
\mathbf{n}(\%)\end{array}$ & $\begin{array}{c}\text { Yes } \\
\mathbf{n}(\%)\end{array}$ & $\begin{array}{c}\text { Does not know } \\
\mathbf{n}(\%)\end{array}$ \\
\hline Breast milk & $66(64.7 \%)$ & $36(35.3 \%)$ & - \\
Main meal & $1(1.00 \%)$ & $101(99.0 \%)$ & - \\
Animal milk & $32(31.4 \%)$ & $70(68.6 \%)$ & $1(1.0 \%)$ \\
Yogurt & $47(46.5 \%)$ & $54(52.5 \%)$ & $1(1.0 \%)$ \\
Leafy vegetables & $55(53.9 \%)$ & $46(45.1 \%)$ & - \\
Filled cookies, sweets and candies & $60(58.8 \%)$ & $42(41.2 \%)$ & - \\
Sweetened beverages & $67(65.7 \%)$ & $35(34.3 \%)$ & - \\
Liver & $80(78.4 \%)$ & $21(20.6 \%)$ & - \\
Hamburgers and/or cold meats & $84(82.4 \%)$ & $18(17.6 \%)$ & - \\
Instant noodles, chips, and cookies & $88(86.3 \%)$ & $14(13.7 \%)$ & \\
Milk oatmeal & $97(95.1 \%)$ & $5(4.9 \%)$ & \\
Consistency of the food provided & & $\mathbf{n}(\%)$ & \\
Sliced & & $92(90 \%)$ & \\
Smashed & & $8(8.0 \%)$ & \\
Blended & & $2(2.0 \%)$ & \\
\hline Total & & $102(100.0 \%)$ & \\
\hline
\end{tabular}

Table 2 - Description of the data from the questionnaire on food intake markers, for children over two years of age, Divinópolis, MG, Brazil, 2019. ( $n=266)$

\begin{tabular}{lccc}
\hline Consumption on the previous day & $\begin{array}{c}\mathbf{N}^{\circ} \\
\mathbf{n}(\%)\end{array}$ & $\begin{array}{c}\text { Yes } \\
\mathbf{n}(\%)\end{array}$ & $\begin{array}{c}\text { Does not know } \\
\mathbf{n}(\%)\end{array}$ \\
\hline Filled cookies, sweets and candies. & $121(45.5 \%)$ & $145(54.5 \%)$ & - \\
Sweetened beverages. & $153(57.5 \%)$ & $112(42.1 \%)$ & $1(0.4 \%)$ \\
Hamburgers and/or cold meats. & $191(71.8 \%)$ & $74(27.8 \%)$ & $1(0.4 \%)$ \\
Instant noodles, chips, and cookies. & $238(89.5 \%)$ & $25(9.4 \%)$ & $3(1.1 \%)$ \\
\hline
\end{tabular}


Regarding the children aged over two years old, the most consumed food was beans $(92.2 \%)$. More than a half of the children in this age group ate their meals while watching television or using the computer and/or cell phone (51.7\%), and had from five to six meals a day (53.4\%) (Table 3 ).

The multivariate analysis showed that the children's consumption of ultra-processed foods was greater when the parents used physical force for the child to eat $(p=0.006)$, gave rewards for eating $(p=0.018)$, and established restrictions for weight control $(p=0.011)$ (Table 4).

A negative association, that is, lower consumption of ultra-processed foods, was identified when the parents provided guidance for healthy eating $(p=0.006)$, authoritative monitoring of the consumption of high-fat foods $(p=0.017)$, and positive reinforcement together with the children regarding the behavior that is considered adequate $(p=0.046)$. With regard to the socioeconomic level, there was no statistically significant association between this variable and the children's eating behavior (Table 5).

Table 3 - Description of the children aged over two years old according to eating practice, Divinópolis, MG, Brazil, 2019. ( $(n=266)$

\begin{tabular}{lcc}
\hline Meals in front of the TV, computer or cell phone & $\mathbf{n}$ & $\%$ \\
\hline No & 129 & 48.3 \\
Yes & 137 & 51.7 \\
\hline Total & 266 & 100.0 \\
\hline
\end{tabular}

Table 4 - Variables associated with the eating behavior of children from two to five years of age living in the urban area, represented by the parenting practices during meals, according to the multivariate linear regression model, Divinópolis, MG, Brazil, 2019. $(n=266)$

\begin{tabular}{lccc}
\hline Variables - PFSQ & Coefficient & $\mathbf{t}$ & p-value \\
\hline Use of physical force with the child for him/her to eat & 316 & 2.759 & .006 \\
Use of a reward for eating & 319 & 2.387 & .018 \\
\hline
\end{tabular}

*Linear Regression test ( $p$-value $<0.05$ ); tReference stratum for associations of the child's eating behavior; $¥ P F S Q$ - Parental Feeding Styles Questionnaire.

Table 5 - Variables associated with the eating behavior of children from two to five years of age living in the urban area, represented by comprehensive parenting practices, according to the multivariate linear regression model, Divinópolis, MG, Brazil, 2019. $(n=266)$

\begin{tabular}{lccc}
\hline Associations with the child's eating behavior & Coefficient & $\mathbf{T}$ & p-value \\
\hline Child's variable - CFPQ & & & \\
Guidance for healthy eating & -3.277 & -2.744 & .006 \\
Authoritative monitoring & -.351 & -2.404 & .017 \\
Restriction for weight control & 312 & 2.557 & .011 \\
Positive reinforcement of adequate child behavior & -.213 & -2.001 & .046 \\
\hline
\end{tabular}

*Linear Regression test ( $p$-value $<0.05$ ); tReference stratum for associations of the child's eating behavior; $\neq C F P Q$

- Comprehensive Feeding Practices Questionnaire 


\section{DISCUSSION}

This study showed that there is an association between parenting practices and the children's eating behavior. Parenting practices such as the use of physical force for children to eat, rewards for eating, and food restriction had a positive association with greater consumption of ultra-processed foods. Similar results were identified in some Brazilian studies that assessed parenting practices of food control and eating behavior. ${ }^{5-6,11-12}$

In São Luis (MA), a study with 114 children from public and private schools investigated the parenting practices of reward and use of foods to control children's emotions and revealed that this dynamics was a constant in children's behavior to deal with negative feelings. ${ }^{5}$ A study conducted with 301 children aged between two and six years old from municipal and private schools, distributed into four areas of the city of Natal, Rio Grande do Norte, verified that the parents' imposing and authoritative behavior does not predict changes in the children's behavior in the medium- to long-term. The authors showed that food restriction for weight control exerted by the parents reduces the child's autonomy and independence for eating, in aspects such as food choices, meal times, and amount to be ingested, thus characterizing an inadequate practice. ${ }^{6}$

In the present research, it was identified that the more frequent the use of physical force practiced by the parents for their children to eat, the greater the consumption of ultra-processed foods by the children. In consonance with our findings, some authors found that the family context plays a relevant role in the learning process, mainly in the strategies that parents use for the child to eat or learn to eat specific foods. ${ }^{7-10}$ These strategies can present inadequate stimuli in the definition of the children's food preferences, leading to loss of control of self-regulation regarding appetite. ${ }^{11,12}$ Another study ${ }^{13}$ also showed that, when parents use corporal or verbal punishment and coercion, children end up developing an exaggerated interest in food.

Parenting practices of rewards had a positive association with greater consumption of ultraprocessed foods. Similar results were identified in other research studies. This phenomenon may be explained by the fact that the use of foods as a reward or as reinforcing stimuli for the child to eat can lead children to perceive food as an award, and consequently, as something valuable and an object of desire, culminating in overfeeding. Therefore, rewards are a negative educational practice that leads to health consequences, such as increased BMI. $., 14,20$

The use of parenting practices involving food restriction favored a greater consumption of ultra-processed foods by the children. These data are in line with those of a study ${ }^{11}$ that evidences the use of food restriction by the parents as a method to control children's food intake and, as a consequence, greater consumption of ultra-processed foods. The authors argue that such practices interfere with the internal signs of hunger and satiety and with the child's self-regulation regarding appetite, fostering the search for hyperpalatable foods and even eating compulsion, with a consequent increase in body weight.

A probable explanation for these results is centered on the fact that parenting practices can represent an act of violence, whether physical or emotional. In fact, children subjected to trauma can develop symptoms in an attempt to find relief, favoring the occurrence of eating disorders such as compulsion, bulimia, and anorexia. In the first case, it could exacerbate the consumption of forbidden foods, thus favoring a greater consumption of processed and ultra-processed products. ${ }^{24}$

According to this research, guidelines for healthy eating, authoritative monitoring, that is, affectionate and understanding, and positive reinforcement to the children's behavior that is considered adequate had a negative association with the consumption of ultra-processed foods. Other studies pointed out that responsive parenting practices such as monitoring and guidance on health eating are protective factors against the consumption of industrialized products, such as cold meats, which supposedly have high salt and sugar content, in the first two years of life. ${ }^{13}$ 
Recent research studies corroborate these findings and highlight that interest in ultra-processed foods was lower among the children whose parents provided guidance for healthy eating, reinforcing the consumption of healthy and tasty foods, monitored them in relation to the consumption of fat-rich foods, and served as a role model by enthusiastically eating healthy foods in front of their children. This explains the correlation between modeling and teaching in nutrition, in which the father or the mother are considered role models for the children's attitudes. ${ }^{15,22}$

In fact, positive monitoring occurs when the parents are aware of what their children do, where they are, their preferences and tastes, and when they show affection for their children, especially during moments of learning and modulation of the eating pattern. In the direction of the belief that moral behavior is also permeated by affection, positive models with moral values such as justice, honesty, charity, empathy, and differentiation of right and wrong favor adequate eating behaviors in children. ${ }^{11}$

Many of the children's eating habits are acquired at home through the parents' actions, which are the first nutrition educators, playing a unique and fundamental role in the development of eating habits during early childhood. . $^{171-22}$ The parents' behavior can exert a direct influence on the child's eating behavior, because it is believed that the several strategies used by the parents to promote the consumption of healthier foods, such as pressure for the child to eat and restriction, are associated with lower regulation of food intake and with greater consumption of children's foods, leading to a negative effect on the child's relationship with food, which can result in weight gain or weight loss. ${ }^{23,25-26}$

Food consumption depends on the child's opportunity of relating to food according to the internal signs of hunger and satiety. With the changes resulting from the globalized world, increasingly processed food products of low nutritional value have been provided; therefore, individuals, families, managers, and society as a whole must be attentive and create opportunities for the consumption of healthy food. . $^{14,22,27}$

It is worth highlighting that more than a half of the children participating in this study eat while watching television or using cell phones and tablets. Although access to technology has been increasingly more frequent nowadays, the literature emphasizes the harms of this practice. ${ }^{23,26}$ Especially with regard to the television media, it is known that some marketing campaigns are specifically targeted at children, stimulating the consumption of industrialized food with high calorie content and low nutritional value, contrary to the current recommendations of the Brazilian Food Guide. ${ }^{14} \mathrm{~A}$ study conducted to assess the habit of watching television while eating in the Brazilian population showed that this habit is associated with the consumption of unhealthy food. ${ }^{27-28}$

In this research, no statistically significant association was identified between socioeconomic level and eating behavior. However, the literature points out that the family food choices are directed to foods that do not require much time for cooking and preparing and that are compatible with their socioeconomic conditions. These choices can lead to an unbalanced diet, with scarcity of nutrients and excess of salt, fat, and sugar. ${ }^{29}$ In fact, a relevant aspect in children's food intake is the provision of low-nutrient foods in the household, and lower income families tend to consume more processed and ultra-processed food products because their prices are more accessible and due to the higher availability to purchase them near their homes, in addition to being easy to prepare. ${ }^{4}$

An important prevalence of excess weight and obesity was identified in this study. Currently, excess weight is a problem of great magnitude. It is known that 3.9 million children in Latin America and the Caribbean are overweight or obese ${ }^{28}$ In this direction, the findings of this study point out that the government, the families, and society as a whole need to implement measures to promote access to and consumption of food products that favor the children's physiological growth and development. In fact, among the seventeen sustainable development goals for the millennium, the second stands out, which reinforces the actions to eradicate hunger and to promote sustainable agriculture, since a deficient diet causes almost half of the deaths of children aged under five years old, and investing on 
small farmers is an important way of improving food safety and increasing the production of healthy food products for local and global markets. ${ }^{30}$ The need to create and develop intervention programs that encompass the parenting educational practices is also pointed out, with a focus on children's eating behavior, so as to prevent future problems and to promote children's health and quality of life.

This study has limitations. The research design allowed estimating the eating behavior of children living in the urban area of the municipality of Divinópolis, as well as its association with the parenting practices but, for being cross-sectional, it did not allow making cause and effect inferences.

\section{CONCLUSION}

The results of this study evidenced that there was an association between parenting practices and the child's eating behavior. The study also pointed out that negative education practices are associated with harms to children's eating behavior, and that positive education practices promote adequate eating habits in children. Longitudinal research studies are recommended, favoring clarification of the issue regarding the cause and effect relationships.

\section{REFERENCES}

1. Vaz DSS, Bennemann RM. Comportamento alimentar e hábito alimentar: uma revisão. Uningá Review [Internet]. 2014 [cited 2019 Oct 28];20(1):108-112. Available from: https://www.mastereditora. com.br/periodico/20141001_083919.pdf

2. Carnell S, Benson L, Driggin E, Kolbe L. Parent feeding behavior and child appetite: associations depend on feeding style. Int J Eat Disord [Internet]. 2014 [cited 2019 Sept 22];47(7):705-9. Available from: https://doi.org/10.1002/eat.22324

3. Ministério da Saúde (BR). Secretária de Atenção à Saúde. Departamento de atenção Básica. Guia alimentar para a população brasileira. 2nd ed. Brasília, DF(BR): Ministério da Saúde; 2014 [cited 2019 Nov 10]. Available from: https://bvsms.saude.gov.br/bvs/publicacoes/guia_alimentar_ populacao_brasileira_2ed.pdf

4. Sousa NFC, Javorski M, Sette GCS, Pontes CM, Santos AHS, Leal LP. Practices of mothers and caregivers in the implementation of the ten steps for healthy feeding. Texto Contexto Enferm [Internet]. 2019 [cited $2020 \mathrm{Jul} 07$ ];28:e20170596. Available from: https://doi.org/10.1590/1980265x-tce-2017-0596

5. Pinheiro-Carozzo NP, Oliveira JHA. Práticas alimentares parentais: a percepção de crianças acerca das estratégias educativas utilizadas no condicionamento do comportamento alimentar. Psic Rev São Paulo [Internet]. 2017 [cited 2019 Oct 11];26(1):187-209. Available from: https:// doi.org/10.23925/2594-3871.2017v26i1p.187-209

6. Maranhão HS, Aguiar RC, Lira DTJ, Sales MUF, Nóbrega NAN. Feeding difficulties in preschool children, previous feeding practices, and nutritional status. Rev Paul Pediatr [Internet]. 2018 [cited 2019 Nov 03];36(1):45-51. Available from: https://doi.org/10.1590/1984-0462/;2018;36;1;00004

7. Horst KVD, Sleddens EFC. Parenting styles, feeding styles and foodrelated parenting practices in relation to toddlers' eating styles: A cluster-analytic approach. PLoS One [Internet]. 2017[cited 2019 Nov 28];12(5):e0178149. Available from: https://doi.org/10.1371/journal.pone.0178149

8. Russell CG, Worsley A, Campbell KJ. Strategies used by parents to influence their children's food preferences. Apetite [Internet]. 2015 [cited 2019 Nov 28];90:123-30. Available from: https:// doi.org/10.1016/j.appet.2015.02.038

9. Jansen E, Williams KE, Mallan KM, Nicholson JM, Daniels L. Bidirectional associations between mothers' feeding practices and child eating behaviours. Int J BehavNutr Phys Act [Internet]. 2018 [cited 2019 Oct 02];15(1):3. Available from: https://doi.org/10.1186/s12966-018-0644-x 
10. Remy E, Issanchou S, Chabanet C, Boggio V, Nicklaus S. Impact of adiposity, age, sex and maternal feeding practices on eating in the absence of hunger and caloric compensation in preschool children. Int J Obes (Lond) [Internet]. 2015 [cited 2019 Nov 25];39(6):925-30. Available from: https://doi.org/10.1038/ijo.2015.30

11. Freitas FR, Moraes DEB, Warkentin S, Mais LA, Ivers JF, Taddei JAAC. Maternal restrictive feeding practices forchild weight controlandas sociated characteristics. J Pediatr (Rio J) [Internet]. 2019 [cited 2019 Nov 29];95(2):201-8. Available from: https://doi.org/10.1016/j.jped.2017.12.009

12. Leung MCA, Passadore MD, Silva SMCS. Fatores que influenciam os responsáveis pela seleção dos alimentos para crianças da educação infantil: uma reflexão bioética num estudo exploratório. Mundo Saúde [Internet].2016 [cited 2019 Oct 21];40(4):490-7. Available from: https:// doi.org/10.15343/0104-7809.20164004490497

13. Melo KM, Cruz ACP, Brito MFSF, Pinho L. Influência do comportamento dos pais durante a refeição e no excesso de peso na infância. Esc Anna Nery [Internet]. 2017 [cited 2019 Jul 10]; 21(4):e20170102. Available from: https://doi.org/10.1590/2177-9465-ean-2017-0102

14. Ministério da Saúde (BR). Política Nacional de Atenção Integral à Saúde da Criança: orientações para implementação. Brasília, DF(BR): Ministério da Saúde; 2018 [cited 2019 June 23]. Available from: http://www.saude.pr.gov.br/arquivos/file/politica_nacional_de_atencao_integral_a_saude_ da_crianca_pnaisc.pdf

15. Osatti AM, Ribeiro LW, Machado RHV, Maximino P, Bozzini AB, Ramos CC, et al. Does family mealtime have a protective effect on obesity and good eating habits in young people? A 20002016 review. Rev Bras Saúde Matern Infant [Internet].2017 [cited 2019 Nov 18];17(3):435-45. Available from: https://doi.org/10.1590/1806-93042017000300002

16. Hellwig N, Neuenfeld TM, Tomasi E. Sintomas depressivos em idosos: estudo transversal de base populacional. Ciênc Saúde Coletiva [Internet]. 2016 [cited 2019 June 12];21(11):3575-84. Available from: https://doi.org/10.1590/1413-812320152111.19552015

17. Ministério da Saúde (BR). Orientações para a coleta e análise de dados antropométricos em serviços de saúde: Norma Técnica do Sistema de Vigilância Alimentar e Nutricional - SISVAN. Brasília, DF(BR): Ministério da Saúde; 2011 [cited 2019 Aug 04]. Available from: http://bvsms. saude.gov.br/bvs/publicacoes/orientacoes_coleta_analise_dados_antropometricos.pdf

18. Associação Brasileira de Empresas de Pesquisa [Internet]. Critério de classificação econômica Brasil; 2011 [cited 2019 Jul 15]. Available from: http://www.abep.org/download

19. Ministério da Saúde (BR). Orientações para Avaliação de Marcadores de Consumo Alimentar na Atenção Básica. Brasília, DF(BR): Ministério da Saúde; 2015 [cited 2019 Nov 25]; Available from: http://bvsms.saude.gov.br/bvs/publicacoes/marcadores_consumo_alimentar_atencao_basica.pdf

20. Warkentin S, Mais LA, Latorre MRDO, Carnell S, Taddel JAAC. Validation of the comprehensive feeding practices questionnaire in parents of preschool children in Brazil. BMC Public Health [Internet]. 2016 [cited 2019 Nov 20];16:603. Available from: https://doi.org/10.1186/s12889-016$3282-8$

21. Nasreddine L, NajaF, AkI C, Chamieh MC, Karam S, Sibai AM, et al. Dietary, lifestyle and socioeconomic correlates of overweight, obesity and central adiposity in Lebanese children and adolescents. Nutrients [Internet]. 2014 [cited 2018 Oct 25];6(3):1038-62. Available from: https:// doi.org/10.3390/nu6031038

22. Organização Pan-Americana da Saúde. Departamento de Doenças não Transmissíveis e Saúde Mental. Alimentos e bebidas ultraprocessados na América Latina: tendências, efeito na obesidade e implicações para políticas públicas. Brasília, DF(BR): OPAS; 2018 [cited 2019 Nov 22]. Available from: https://iris.paho.org/bitstream/handle/10665.2/34918/9789275718643-por. pdf?sequence $=5 \&$ isallowed $=y$ 
23. Cauduro GN, Reppold CT, Pacheco JTB. Adaptação transcultural do questionário de estilos parentais na alimentação (QEPA). Aval Psico [Internet]. 2017 [cited 2019 Nov 20];16(3):293-300. Available from: https://doi.org/10.15689/ap.2017.1603.12452

24. Rosaria JM. Can violence cause eating disorders? Psychiatr Danub [Internet]. 2015 [cited 2020 Jul 08];27(1):336-8. Available from: https://pesquisa.bvsalud.org/portal/resource/pt/mdl-26417791

25. Moura TNB, Moreira TMM, Sousa AD, Santos AC Neto, Sousa RX, Lima LHO. Development and validation of a smartphone educational game regarding healthy lifestyle habits for adolescents. Texto Contexto Enferm [Internet]. 2019 [cited 2019 Nov 10];28:e20180252. Available from: https:// doi.org/10.1590/1980-265x-tce-2018-0252

26. Haines J, Downing KL, Tang L, Campbell KJ, Hesketh KD. Associations between maternal concern about child's weight and related behaviours and maternal weight-related parenting practices: a cross-sectional study. Int J Behav Nutr Phys Act [Internet]. 2018 [cited 2020 Jul 7];15(1):104. Available from: https://doi.org/10.1186/s12966-018-0738-5

27. Maia EG, Gomes FMD, Alves MH, Huth YR, Claro RM. Hábito de assistir à televisão e sua relação com a alimentação: resultados do período de 2006 a 2014 em capitais brasileiras. Cad Saúde Pública [Internet]. 2016 [cited 2019 Jul 28];32(9):e00104515. Available from: https://doi. org/10.1590/0102-311X00104515

28. Organização das Nações Unidas para Alimentação e a Agricultura [Internet]. FAO; 2017 [cited 2019 Nov 19]. Available from: https://nacoesunidas.org/agencia/fao/

29. Cristiano S, Boccolini PMM, Monteiro FR, Venâncio SI, Giugliani ERJ. Tendência de indicadores do aleitamento materno no Brasil em três décadas. Rev Saúde Pública [Internet]. 2017 [citado 2020 Jul 07];51:108. Available from: http://www.scielo.br/scielo.php?script=sci_arttext\&pid=S0034$89102017000100287 \&$ Ing $=p t$

30. Brasil. Ministério da Saúde. Vigilância de Fatores de Risco e Proteção para Doenças Crônicas por Inquérito Telefônico. Brasília, DF(BR): Ministério da Saúde; 2018 [cited 2019 Nov 28]. Available from: https://bvsms.saude.gov.br/bvs/publicacoes/vigitel_brasil_2017_vigilancia_fatores_riscos.pdf 


\section{NOTES}

\section{ORIGIN OF THE ARTICLE}

Extracted from the thesis - Parenting practices and their relationship with children's eating behavior, presented to the Programa de Pós-Graduação em Enfermagem, Universidade Federal de São João Del Rei, Campus Centro-Oeste Dona Lindu, in 2019.

\section{CONTRIBUTION OF AUTHORITY}

Study design: Santos KF, Romano MCC, Reis MA.

Data collect: Santos KF.

Discussion of the results: Santos KF, Romano MCC.

Writing and / or critical review of content: Santos KF, Romano MCC, Reis MA.

Review and final approval of the final version: Santos KF, Romano MCC.

\section{APPROVAL OF ETHICS COMMITTEE IN RESEARCH}

Approved by the Ethics Committee in Research with Human Beings of the of the Universidade Federal de São João Del Rei, under consubstantiated opinion No.3,330,967 and CAAE No. 98529018.0.0000.5545.

\section{CONFLICT OF INTEREST}

There is no conflict of interests.

\section{EDITORS}

Associated Editors: Selma Regina de Andrade, Gisele Cristina Manfrini, Elisiane Lorenzini, Ana Izabel Jatobá de Souza.

Editor-in-chief: Roberta Costa.

\section{HISTORICAL}

Received: May 08, 2020.

Approved: July 20, 2020.

\section{CORRESPONDING AUTHOR}

Kelly de Freitas Santos

kellyfreitass83@hotmail.com 